\title{
PENDIDIKAN MORAL KIDS ZAMAN NOW DALAM PERSPEKTIF ISLAM
}

\author{
Akhmad Aufa Syukron \\ UIN Sunan Kalijaga Yogyakarta \\ Email: akhmadaufasyukron88@gmail.com
}

\begin{abstract}
This paper seeks to photograph the thinking of moral education of children today in the perspective of Islam. The term children nowadays in Indonesian is known as Kids Zaman Now. Kids Zaman Now is actually as satire refers to unnatural behavior of children today. Moral education is a set of basic moral principles and virtues of attitudes and temperaments that must be owned and made habit by the child from the beginner until he became a mukallaf, ready to wade through the sea of life. In the modern era, the problems that arise are physical and psychological problems. Physical problems lead to human conditioning as the object of all science and technology products. This research is library research. This research collects text data. In this case the author held the collection of books, articles, internet data and journals that have relevance to the subject of the study author. To deal with Kids Zaman Now problematic, what is needed is morality that comes from al-Quran and al-Hadist. The integration and interconnection between al-Quran al-Hadith with Science becomes the solution to the creation of a moral life and without diminishing the progress of science itself. This will make children today become children who are not behind the times (science and technology) is also a child who morality. The people's perspective will also not look at Kids Zaman Now as an unscrupulous child but Kids Zaman Now who are madaments and achievers in the advancement of science and technology.
\end{abstract}

Keywords : Kids Zaman Now, Modern Man, Moral Education

\begin{abstract}
Abstrak: Tulisan ini berusaha memotret pemikiran pendidikan moral anak zaman sekarang dalam perspektif Islam. Istilah anak zaman sekarang di Indonesia lebih dikenal dengan Kids Zaman Now. Kids Zaman Now sebenarnya merupakan sindirian pada kelakuan tidak wajar dari anak zaman sekarang. Pendidikan moral merupakan serangkaian prinsip dasar moral dan keutamaan sikap serta watak yang harus dimiliki dan dijadikan kebiasaan oleh anak sejak masa pemula hingga ia menjadi seorang mukallaf. Di era modern, persoalan yang muncul adalah persoalan fisik dan psikis. Persoalan fisik mengarah pada pengkondisian manusia sebagai objek dari segala produk sains dan teknologi. Penelitian ini merupakan penelitian kepustakaan (library research). Penelitian ini menghimpun data teks. Dalam hal ini penulis mengadakan pengumpulan buku, artikel, data internet maupun jurnal yang memiliki relevansi dengan pokok kajian penulis. Untuk menghadapi problematika Kids Zaman Now, yang diperlukan adalah akhlak yang bersumber pada al-Quran dan al- Hadist. Integrasi dan Interkoneksi antara al-Quran al-Hadis dengan Sains menjadi solusi agar terciptanya kehidupan yang bermoral dan tanpa menghilangkan kemajuan sains itu sendiri. Hal ini akan membuat anak zaman sekarang menjadi anak yang tidak ketinggalan zaman (sains dan teknologi) juga menjadi anak yang berakhlakul karimah. Perspektif masyarakat juga tidak akan memandang Kids Zaman Now sebagai anak yang tidak bermoral melainkan Kids Zaman Now yang berakhlakul karimah dan berprestasi dalam kemajuan sains dan teknologi.
\end{abstract}

Kata Kunci:, Kids Zaman Now, Manusia Modern, Pendidikan Moral 


\section{Pendahuluan}

Pendidikan adalah pagar atau batas dari manusia untuk melakukan suatu tindakan. Di dalam pendidikan ada nilai moral dan tingkah laku. Kita dapat mengetahui orang yang berpendidikan atau tidak dari cara dia berperilaku dan perbuatan mereka setiap hari, apakah berperilaku baik atau tidak. Jadi pendidikan adalah cerminan diri kita dihadapan masyarakat. Pendidikan yang baik harus kita tanam dari kecil dari orangtua, di sekolah, maupun di lingkungan masyakat, agar melahirkan generasi yang bermoral dan berperilaku baik.

Pendidikan merupakan komponen penting dalam kehidupan manusia. Tanpa pendidikan kehidupan manusia tidak bisa berkembang secara wajar. Oleh karena pentingnya pendidikan maka pendidikan menjadi tolak ukur dalam kredibilitas manusia dan peradabannya. Sebagaimana Hanik Yuni Alifiyah (2008:1) dalam bukunya yang berjudul Ta'lim dan Liberasi menerangkan bahwa "Semakin tinggi tingkat pendidikan manusia maka semakin tinggi pula tingkat kredibilitasnya, begitu sebaliknya, semakin rendah tingkat pendidikan manusia maka semakin dipertanyakan tingkat kredibilitas kemanusiaannya".

Pendidikan hendaknya berorientasi pada proses penyiapan peserta didik agar memahami konsep-konsep dasar tentang berprilaku, berfikir secara komprehensif dan integral sebagai pijakan dalam menghadapi berbagai problem yang dihadapinya. Pendidikan juga bertujuan agar peserta didik memiliki kompetensi-kompetensi menyangkut ilmu pengetahuan, keterampilan motorik, dan nilai-nilai moral yang luhur serta mencapai manusia yang memiliki kepribadian yang dipenuhi dengan sifat-sifat Ilahiah (ketuhanan).

Selama ini Pendidikan moral termasuk di antara jenis pendidikan yang kurang mendapatkan perhatian layak. Sebab pendidikan lebih menekankan kepada ranah kognitif dan psikomotorik (cognitive and psychomotoric domain) sehingga aspek afektif (affective domain) belum dilaksanakan secara proporsional. Padahal ranah afektif menempati posisi penting dan signifikan bagi normalisasi kehidupan.

Dalam kehidupan di tengah-tengah masyarakat terlihat jelas seolah-olah terjadi dua hal yang sangat paradoks. Pada satu sisi terlihat syiar dan gebyar kehidupan beragama, tetapi di sisi lain dengan mudah disaksikan akhlak masyarakat berubah makin jauh dari nilai-nilai Qurani. (Said Agil, 2005:36). 
Said Agil (2005:33) menyimpulkan bahwa:

Tumbuh suburnya praktik KKN, kenakalan remaja, dekadensi moral, penyalahgunaan narkotika dan obat terlarang, tawuran antar mahasiswa atau siswa atau penduduk, ketidakjujuran dalam mengerjakan ujian (termasuk ujian nasional), dan masih banyak lagi, menjadi bukti lemahnya iman dan rendahnya nilai-nilai yang dimiliki oleh seorang anak manusia. Hal ini ironis, karena krisis moral sama artinya dengan krisis akal.

Penekanan pendidikan yang lebih pada aspek kognitif dan psikomotorik dengan kurang memerhatikan pelaksanaan aspek afektif pada lembaga pendidikan hanya akan menghasilkan manusia yang pintar secara intelektual dan ketrampilan, tetapi rendah dan bobrok moral atau akhlaknya. Konsekuensinya, out put lembaga pendidikan menjadi orang yang cerdik pandai (ilmuwan) tetapi bermental jahat sehingga mereka menjadi pejabat yang berjiwa KKN, teknokrat yang membuat kerusakan lingkungan hidup, konglomerat yang bermental penjudi, dan sebagainya, (Said Agil, 2005:25). Realitas tersebut menunjukkan urgennya penanaman nilai-nilai moral pada diri anak didik.

Permasalahan di atas memicu penulis untuk menganggap dan meyakini pentingnya pendidikan moral dikedepankan. Dalam kaitan ini, signifikan dengan pemikiran Abdullah Nasih Ulwan tentang persoalan-persoalan seputar pendidikan yang penuh dengan pesanpesan moral. Abdullah Nasih Ulwan, dalam bukunya Tarbiyatul Awlad fil Islam banyak mengupas tentang konsep pendidikan anak dalam Islam yang berisi tentang pesan-pesan moral, sebagaimana dikutip oleh Mustofa Rohman (2003:47) bahwa: Abdullah Nasih Ulwan menawarkan upaya pendidikan nilai atau moral ini dengan cara menanamkan dasar-dasar psikis yang mulia berdasarkan keimanan untuk memelihara hak orang lain guna merealisasikan etika sosial dengan pengawasan dan kritik sosial sehingga tumbuh sikap dan perilaku sosial yang menjunjung tinggi nilai-nilai persaudaraan dan kasih sayang agar terwujud masyarakat yang peduli untuk melaksanakan seruan Amar Ma'ruf Nahi Munkar. Dan peran orangtualah yang paling menonjol menciptakan anak-anak yang yang bermoral, melalui ajaran orangtua dari kecil hingga dia siap untuk menghadapi kehidupan dengan bermasyarakat. Walaupun sifat anak mempelajari agama di waktu kecil masih bersifat meniru apa yang di ajarkan oleh orangtua, hal ini menjadi dasar mereka ketika remaja dan dewasa. Apabila orangtua mengajari anak tentang agama dengan benar maka moralnya juga benar ketika dia dewasa. 
Konsep dasar anak dilahirkan dalam keadaan fitrah. Dalam sebuah hadits Abu Hurairah Radhiyallahu'anhu sebagaimana dikutip Zainuddin Ahmad (2003:155):

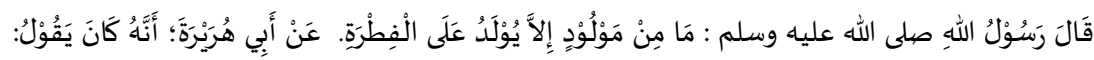

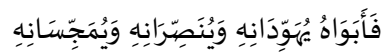

Hadis riwayat Abu Hurairah Radhiyallahu'anhu, ia berkata: Rasulullah Shallallahu alaihi wassalam bersabda: Setiap anak itu dilahirkan dalam keadaan fitrah. Kedua orang tuanyalah yang membuatnya menjadi seorang Yahudi, seorang Nasrani maupun seorang Majusi. Sebagaimana seekor binatang yang melahirkan seekor anak tanpa cacat, apakah kamu merasakan terdapat yang terpotong hidungnya?.

Maksud dari hadits di atas adalah pengaruh orangtualah yang paling dominan mempengaruhi anaknya menjadi seorang Yahudi, Nasroni, maupun seorang Majusi walaupun fitrah anak tersebut adalah Islam. Disini seorang anak menjadi seorang yahudi, nasroni, mapun majusi bukan dari segi kepercayaannya melainkan dari segi pemikirannya, berpikir seperti orang yahudi, berpikir seperti orang nasroni dan berpikir seperti orang majusi. Faktanya di Indonesia banyak sekali bermunculan meme Kidz Zaman Now yang dikaitkan dengan tingkah laku anak-anak zaman sekarang yang negatif, yang mengikuti budaya barat, dari segi penampilan hingga tingkah laku yang serba modern, tanpa memandang nilai moral di dalam penampilan maupun perbuatan.

Maka dari itu orang tua sangatlah penting menjaga dan mendidik anak disetiap proses baik sebelum kelahirannya hingga sampai ia mampu hidup bersama dengan orang lain. Karena pendidikan orangtua akan mempengaruhi kehidupan anak di zaman modern saat ini, apakah anak menjadi anak yang bermoral dan berprestasi atau bertindak arogan dan tidak terkendali.

Anak adalah tunas-tunas harapan tumbuhnya peradaban baru yang lebih humanis. Pada merekalah kehidupan manusia ditentukan keberlangsungannya. Anak-anak akan menciptakan dunia baru dengan segala interpretasi dan kreasinya. Jika anak-anak memiliki spiritualitas dan moralitas yang baik maka baik juga peradaban yang mereka bangun. Namun sebaliknya jika spiritualitas dan moralitas mereka buruk, maka buruklah kehidupan itu, (Sigit Mangun Wardoyo, 2014:50) 
Proses pengenalan anak dengan lingkungannya adalah suatu proses pembelajaran di mana anak akan belajar dari segala sumber belajar yang ada di sekelilingnya. Anak-anak akan belajar dari perilaku keluarga, komunitas, masyarakat, sekolah dan lingkungan lainnya. Oleh kerena itulah, interaksi anak dengan sumber belajar diharapkan menciptakan interaksi positif yang mampu membangun spiritualitas dan moralitas anak dengan baik.

Pendidikan sebagai proses pembentukan manusia menjadi fondasi penting dalam membentuk karakter anak. Dengan merealisasikan pendidikan yang dititikberatkan pada pembangunan spiritualitas diharapkan moralitas anak terbentuk secara baik. Harapannya adalah dari pembangunan spiritualitas melalui pendidikan, moralitas anak terbentuk secara baik dan akhirnya berdampak pada peradaban manusia kedepannya.

Pendidikan memiliki konstribusi yang sangat besar terhadap fenomena dekandensi moral masyarakat. Isu terkait dengan semakin pudarnya moralitas yang dimiliki masyarakat semakin merebak. Fakta menunjukkan bahwa penggunaan narkotika atau obat-obatan terlarang, perzinahan, pelacuran, perjudian, pengguguran kandungan, pembunuhan dan tindakan kriminal lainnya sudah menjadi masalah sosial yang semakin jelas dalam kehidupan bermasyarakat.

Oleh karena itu, untuk membentengi anak dari fenomena dan permasalahan tersebut, harus dilakukan langkah kongrit sebagai fondasi yang kuat dalam membentuk anak yang bermoral. Langkah tersebut dilakukan dengan membangun nilai-nilai spiritualitas dalam diri anak melalui proses pendidikan yang baik yang dilakukan dalam keluarga, sekolah, dan masyarakat.

\section{Metode Penelitian}

Penelitian ini merupakan penelitian kepustakaan (library research). Penelitian ini menghimpun data teks. Dalam hal ini penulis mengadakan pengumpulan buku, artikel, data internet maupun jurnal yang memiliki relevansi dengan pokok kajian penulis. Literatur yang dijadikan sumber data dalam penelitian ini adalah sumber primer ("Kids Zaman Now; Zaman Now : Pengertian, Asal Usul, dan Penulisan Yang Benar" dalam http://www.romelteamedia.com/2017/11/zamannow-pengertian-asal-usul.html, "Pengertian Istilah Zaman Now" dalam https://www.kompasiana.com/maunareng/59fd5d7374bbb02c55408 b32/pengertian-istilah-zaman-now, dan "Kids Zaman Now Suksesor Generasi Millenials" dalam http://www.jurnalcowok.com/2017/10/kids-jaman-now-adalah.html; 
dan sumber sekunder karya Kadar M. Yusuf; Tafsir Tarbawi: PesanPesan al-Qur'an Tentang Pendidikan(2013), Ahmad Munir; Tafsir Tarbawi: Mengungkap Pesan al-Qur'an Tentang Pendidikan (2008), dan Johan Istiadie \& Fauti Subhan; Pendidikan Moral Perspektif Nasih Ulwan (2013) serta sumber pendukung (berbagai referensi yang terkait dengan tema penelitian).

Dalam melakukan pengolahan data yang berkaitan dengan fokus perspektif Islam tentang Pendidikan Moral Kids Zaman Now, penulis menggunakan tahapan-tahapan sebagai berikut: Deskripsi data, Interpretasi data, dan Analisis data. Analisis yang digunakan adalah analisis isi (content analysis).

\section{Hasil Penelitian}

\section{Pengertian Kids Zaman Now}

Istilah Kids Zaman Now sebenarnya merupakan guyonan sekaligus sindirian (satire) merujuk pada kelakuan "aneh" atau tidak wajar dari anak-anak zaman sekarang. Secara bahasa, Kids Zaman Now artinya anak-anak zaman sekarang. Zaman Now gabungan bahasa Indonesia, Zaman dan bahasa Inggris Now (sekarang).

Kata Kids Zaman Now yang menyebar di netizen bukan kata zaman tetapi jaman, padahal menurut penulisan kata baku Kamus KBBI bukan kata jaman yang baku melainkan kata zaman, (Romel Tea, Pengertian, Asal Usul, dan Penulisan Yang Benar , http://www.romelteamedia.com/2017/11/zaman-now-pengertianasal-usul.html, diakses 3 Januari 2018 pukul 20:00).

Istilah Kids Zaman Now adalah sindirian atau kritikan terhadap perilaku anak-anak muda sebenarnya bukan hal baru, melainkan sudah lama bahkan sejak zaman Koes Plus, yaitu era 1970-an sudah ada lagu "Muda Mudi" yang menggambarkan perilaku anak muda "zaman now" saat itu. Akan tetapi menjadi viral pada zaman modern ini ketika masyarakat menilai anak muda bahkan anak yang belum cukup umur bergaya penampilan serba aneh dan hanya ingin narsis di sosial media.

Sebuah artikel online oleh kompasiana menjelaskan pengertian penggunaan istilah zaman now seperti ini:

Bagi warganet (netizen, citizen), penggunaan istilah zaman now bukanlah sesuatu yang asing. Istilah ini sering dimunculkan dalam berbagai komentar dan aktivitas netizen selama berselancar di media internet. Awalnya netizen menggunakan istilah Kids jaman now, kini hanya frase zaman now yang mengikuti kata lain sebagai pengganti kata kids. Misalnya, gubernur zaman now, orang tua 
zaman now, mahasiswa zaman now, sekolah zaman now, dan lainlain, (Fredy Maunareng, Pengertian Istilah "Zaman Now", https://www.kompasiana.com/maunareng/59fd5d7374bbb02c554 08b32/pengertian-istilah-zaman-now diakses 3 Januari 21:00).

Entah siapa yang pertama kali dan di mana dimunculkan, istilah zaman now ini kerap digunakan. Istilah ini pernah juga di-tweet oleh acount twitter @kemdikbud.ri untuk menjelaskan penulisannya yang benar. Awalnya warganet sering menulis jaman now, dan disarankan yang benarnya adalah zaman now; dan lebih baik lagi ialah menggunakan padanannya dalam bahasa Indonesia, yaitu zaman sekarang.

Dalam ilmu linguistik (ilmu bahasa), bentuk zaman now terdiri atas dua kata, yakni zaman dan now. Secara etimologi, kata zaman berasal dari bahasa Indonesia yang artinya (1) jangka waktu yang panjang atau pendek yang menandai sesuatu; masa, dan (2) kala; waktu. Sementara nowadalah kata yang berasal dari bahasa Inggris yang bisa diartikan 'sekarang'. Dengan demikian secara harafiah zaman now dapat diartikan sebagai 'zaman sekarang' atau 'masa kini' atau juga 'saat ini'.

Sebuah kata atau frase yang menjadi sebuah istilah bisa terjadi perubahan makna (semantic change). Perubahan ini bergantung pada konteks penggunaannya. Istilah zaman now adalah istilah yang ditarik dari "Kids jaman now" sebagaimana yang digambarkan sebelumnya. Penggunaan istilah "kids jaman now" menggambarkan keadaan anakanak zaman sekarang. Jika mengaitkan kebiasaan anak-anak zaman sekarang dengan yang sebelumnya, kita akan menemukan hal-hal yang berbeda di situ. Misalnya, gaya hidup yang bergantung pada gadget. Apapun yang dilakukan selalu diabadikan dengan kamera atau bahasa kerennya selfie. Ditulis oleh Fredy Maunareng (Fredy Maunareng, Pengertian "Zaman Now", https://www.kompasiana.com/maunareng/59fd5d7374bbb02c55408b3 2/pengertian-istilah-zaman-now diakses 3 Januari 21:00) Mau makan, harus selfie; sedang tidur, selfie juga; sedang menangis karena patah hati dicuekin atau ditinggalkan pacar, selfie juga; bahkan mau bunuh diri juga selfie juga.

Tidak sebatas mengabadikan gambar, setelah selfi tidak afdol kalau tidak di-posting. Makan di KFC, di-post. Padahal mungkin baru sekali masuk KFC. Kalau sedang makan ubi bakar mungkin akan berpikir beberapa kali sebelum di-posting. Sedang tidur di-post dengan gambar tertutup mata, lalu keterangan gambar "sedang tidur". Lucu bukan. Siapa yang tidur, siapa yang mencet kamera. Begitulah kira-kira 
gambaran "kids jaman now". Demikian dipahami bahwa istilah "kids jaman now" adalah suatu kebiasaan remaja masa kini yang berbeda dengan remaja masa lalu. Perbedaan itu cenderung berkonotasi negatif--terlalu berlebihan dari yang sewajarnya.

Dalam sebuah artikel online oleh Fredy Maunareng menjelaskan mengenai istilah zaman now:

Konteks penggunaan suatu kata atau frase yang menjadi sebuah istilah bisa mengalami perubahan atau juga pergeseran makna. Istilah zaman now ini sering dilekatkan mengikuti kata yang lain dengan pengertian yang sama. Inilah perlikau generalisasi (perluasan) semantis. Dengan kata lain, sebuah kata mengalami perluasan arti daripada yang sebelumnya. Istilah dulu hanyalah "kids jaman now", kini apapun bisa dilekatkan dengan zaman now, misalnya ayah zaman now, dan lain-lain. Inilah salah satu fakta bahwa bahasa bersifat kreatif sebagaimana dikatakan Noam Chomsky, pakar bahasa generatif. (Fredy Maunareng, Pengertian Istilah "Zaman Now", https://www.kompasiana.com/maunareng/59fd5d7374bbb02c554 08b32/pengertian-istilah-zaman-now, diakses 3 Januari 21:00).

Jadi zaman now tidak sekedar memiliki arti 'masa kini' atau 'zaman sekarang' semata, tetapi lebih dari itu. Istilah zaman now memiliki arti "berbeda dari lazimnya". Seperti itulah gambaran arti istilah zaman now.

Ditulis dalam artikel online oleh jurnal cowok (Jurnal Cowok, Kids Zaman Now Adalah Suksesor Generasi Millenials?, http://www.jurnalcowok.com/2017/10/kids-jaman-now-adalah.html, diakses 4 Januari 2018 pukul 8:30) Ungkapan Anak Zaman Now ini sendiri ramai dipergunakan oleh netizen (warganet) dari Indonesia dan Malaysia di twitter dan facebook.

Pada praktiknya, istilah ini digunakan untuk mengomentari atau lebih tepatnya mencibir (nyinyirin) perilaku anak jaman sekarang (plural: anak-anak jaman sekarang) yang dianggap aneh, nyeleneh, kurang pantas ataupun absurd.

Selanjutnya Jurnal Cowok menyimpulkan (Jurnal Cowok, Kids Zaman Now Adalah Suksesor Generasi Millenials?, http://www.jurnalcowok.com/2017/10/kids-jaman-now-adalah.html, diakses 4 Januari 2018 pukul 8:30) Jika ditelusuri dari subjek pengguna istilah dan objek istilah ini, kita bisa simpulkan bahwa objek istilah ini adalah generasi $\mathrm{Z}$, atau generasi sesudah Millennials, artinya anak-anak muda yang lahir setelah tahun 2000. 
Dalam sebuah artikel online oleh jurnal cowok menerangkan generasi kidz zaman now:

Millennials menganggap Kids Zaman Now sebagai generasi norak. Dari kecenderungan komentar netizen menggunakana istilah ini, terdapat subliminal message yang menunjukkan ketidaksukaan Millennials pada generasi suksesornya. Meski begitu, perilaku anak jaman sekarang, yang menjadi objek nyinyiran tersebut memang cenderung kelewatan dan norak. Anak-anak jaman sekarang digambarkan sebagai generasi yang terlalu cepat dewasa, terlalu cepat berdandan, terlalu cepat bergaul dan pacaran. Padahal kakak-kakaknya yang dari generasi Millennials belum tentu punya pacar dan mungkin masih kesulitan untuk bisa PDKT lewat chat atau sekedar menarik perhatian wanita. Tidak mengherankan bila fenomena ini memicu lahirnya berbagai meme yang menyindir kelakuaan-kelakuan absurd kids zaman now ini!. Anak-anak ini juga melek internet dan mereka sadar telah menjadi bahan nyinyiran. Generasi muda ini justru menanggapi nyiyiran ini dengan menyerang balik generasi Millennials yang mengejek mereka dengan Ahjussi Jaman Jigeum dan Nongkrong Jaman Old. Istilah ahjussi jaman jigeum ini merupakan penggabungan dari bahasa Korea dan Indonesia. Ahjussi artinya paman atau o'om (panggilan untuk orang yang tuanya setara orangtua kita, sedangkan jigeum artinya sekarang (sama dengan now). Jadi ahjussi jaman jigeum artinya adalah om-om jaman sekarang. Sementara Nongkrong Jaman Old adalah sebuah sindiran balik untuk generasi Millenials yang hobby nongkrong di coffee shop atau cafe-cafe untuk bergaul dan membangun relasi. Bagi anak-anak jaman sekarang atau kids jaman now, mereka lebih suka nongkrong lewat group chat atau game. Bukan hal baru apabila dua generasi berbeda mengalami perbenturan, sama halnya dengan generasi Millennials yang dulu clash dengan gen-X dan baby boomer (Jurnal Cowok, Kids Zaman Now Adalah Suksesor Generasi Millenials? http://www.jurnalcowok.com/2017/10/kids-jaman-nowadalah.html, diakses 4 Januari 2018 pukul 8:30).

\section{Pendidikan Moral Kids Zaman Now Menurut Islam}

\section{Pendidikan Moral Dalam Islam}

$$
\begin{aligned}
& \text { Dalam Q.S al-Isra' ( (17) : 23-24) : }
\end{aligned}
$$

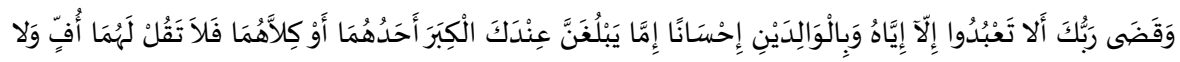

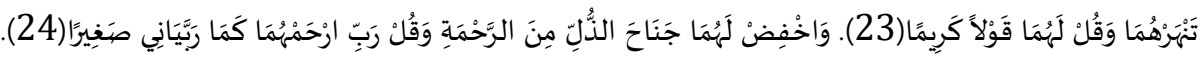


Dan Tuhanmu telah memerintahkan supaya kamu jangan menyembah selain Dia, dan hendaklah kamu berbuat baik pada ibu bapakmu dengan sebaik-baiknya. Jika salah seorang di antara keduanya atau kedua-duanya sampai berumur lanjut dalam pemeliharaanmu, maka sekali-kali janganlah kamu mengatakan kepada keduanya perkataan "ah" dan janganlah kamu membentak mereka dan ucapkanlah kepada mereka perkataan yang mulia. Dan rendahkanlah dirimu terhadap mereka berdua dengan penuh kesayangan dan ucapkanlah: "Wahai Tuhanku, kasihilah mereka keduanya, sebagaimana mereka berdua telah mendidik aku di waktu kecil”,(QS. Al-Isra (17): 23-24).

Kata rabbayaani (mendidik) yang disebutkan dalam ayat di atas adalah teladan amal kebajikan yang dilakukan orang tua kepada anaknya yang tak terhingga nilai jasanya, oleh karena itulah Allah SWT mewajibkan kepada anak untuk berbakti terhadap kedua orang tuanya dengan cara sebaik-baiknya. Dari sinilah kita mengetahui prinsip pendidikan moral dalam Islam serta pentingnya peran orangtua dalam mendidik anaknya, agar anak kita menjadi anak yang bermoral (senantiasa berbakti) kepada orangtua.

Ungkapan tersebut merupakan do'a seorang anak kepada orang tuanya sebagai bentuk rasa syukur atas jasa yang telah diterima semasa kecilnya. Sementara imbalan yang harus diberikan oleh anak kepada orangtuanya dalam ayat tersebut diungkapkan dengan kata waqadha. Kata qadha secara etimologi mempunyai beberapa arti di antaranya; perintah (al-amr) seprti perintah untuk tidak menyembah kecuali hanya kepada Allah, penciptaan (al-kholq), keputusan (alhukmu), kekosongan waktu (al-faragh), kehendak (al-iradah), dan janji (al-'ahdu). Ahmad Munir \& Ainur Rofiq Adnan, (2008:36-37) menyimpulkan bahwa : "Jika kata al-qadha'a diartikan seperti di atas, maka tidaklah relevan jikalau kemaksiatan yang dilakukan manusia telah ditentukan Allah. Karena jika benar, maka tidak ada alasan untuk melakukannya. Padahal Allah tidak pernah memerintahkan hal tersebut".

Selanjutnya Ahmad Munir \& Ainur Rofiq Adanan (2008:37) menjelaskan bahwa: "Ketaatan yang harus dilakukan anak sebagai balasan terhadap orang tuanya, al-Qur'an mensifati perbuatan tersebut dengan : ihsan, dilarang bertutur kasar, anjuran bertutur kata yang baik dan sikap ramah. Hal inilah yang menjadi ciri-ciri anak yang bermoral baik bukan hanya kepada orangtuanya saja, melainkan kepada orang lain atau masyarakat". Berikut adalah ciri-ciri anak yang bermoral dalam Islam: (Ahmad Munir \& Ainur Rofiq Adnan, 2008:37- 
39).

\section{a. Ihsan}

Kata ihsan berasal dari kata hasanun atau husnun yaitu ungkapan untuk menyatakan segala bentuk keindahan yang menjadi kegemaran. Suatu keindahan dapat dikategorikan menjadi tiga aspek, yaitu aspek emosi (al-hawa), indra (al-hassu) dan rasio (al-'aql). Ketaatan kepada orangtua dalam ayat tersebut tidak diikat dengan sifat yang ada pada keduanya, apakah ia kafir atau muslim, karena pengabidan tersebut merupakan janju yang harus dilaksanakan.

Dari sinilah kita mengetahui makna Ihsan yaitu menyatakan segala bentuk keindahan artinya perbuatan yang baik yang memberi manfaat untuk orang lain.

\section{b. Dilarang Bertutur Kasar}

Larangan tersebut pertama diungkapkan dengan kata uffin yang berarti perbuatan yang kotor, jijik yang harus dijauhi. Secara bahasa kata uff berarti dekil, kotoran telinga, potongan kuku yang hitam yang menjijikkan perasaan orang yang melihatnya, yang dilarang untuk diperdengarkan kepada orang yang berumur lanjut.

Larangan kedua tidak boleh membentak, yang diungkapkan dengan kata tanhar. Secara etimologi kata nahr berarti menggali, mengorek kulit yang dapat mengalirkan darah. Ibnu Katsir menafisrkan kata tersebut sebagai sinonim kata uffin, kata uffin ungkapan yang menyakitkan, sedangkan nahr adalah perlakuan yang didasarkan pada emosi dan amarah yang menyakitkan baik secara fisik maupun psikis.

Dalam ayat ini, seorang anak dilarang berkata kasar dan membentak kepada orangtua. artinya secara umum ayat ini menjelaskan bukan hanya kepada orangtua saja dilarang bertutur kasar dan membentak melainkan kepada orang yang lebih tua daripada kita.

\section{c. Anjuran Bertutur Kata Yang Baik}

Setelah Allah melarang bertutur kasar dan bertindak yang tidak sopan, Allah memerintahkan kata yang baik, sopan dan penuh penghormatan yang disifati dengan sifat kariim. Kata tersebut jika dilihat dari sejarah turunnya merupakan sifat Allah yang disebutkan pada awal pewahyuan setelah sifat pencipta kholq, yang menunjukkan moral yang dibangun oleh Islam. 


\section{d. Sikap Ramah}

Sikap ramah anak terhadap orang tuanya yang diungkapkan dengan kata janakh merupakah metaforis dari sikap belas kasih sayang anak terhadap orangtua yang sudah renta, sebagaimana sikap belas kasih orangtua terhadap anak semasa kecil. Kelembutan belas kasih sayang tersebut diumpamakan seekor burung yang membentangkan sayapnya untuk melindungi anaknya dari bahaya, padahal dirinya sendiri belum tentu ada jaminan yang melindunginya. Hal tersebut dilakukan semata-mata sebagai bentuk kepedulian dan curahan kasih sayangnya.

Sementara kata ad-dzulli, adalah ketundukan yang penuh patuhan tanpa ada paksaan dan sikap yang menyusahkan untuk diatur. Hal ini dimaksudkan agar manusia dalam melakukan hubungan dengan orangtua dan manusia secara umum agar selalu tunduk dan patuh dalam kebaikan, baik dari segi ucapan, tingkah laku, maupun pikiran.

Dari ciri-ciri anak yang bermoral di atas, Allah mewajibkan seorang anak untuk berbuat baik, tidak berkata kasar, perkataan yang baik dan bersikap ramah kepada kedua orangtua. Hal inilah yang akan melahirkan anak-anak yang bermoral. Berdasarkan pandangan di atas para ahli merumuskan tujuan pendidikan Islam, yaitu "membentuk peserta didik menjadi insan yang shaleh dan bertakwa kepada Allah SWT", (Kadar M. Yusuf, 2013:82). Sebagaimana Firman Allah SWT:

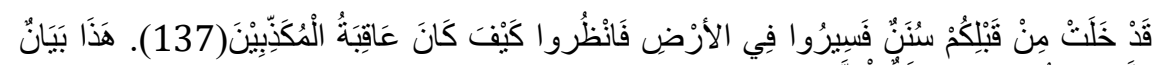

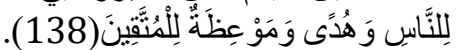

Sungguh, telah berlalu sebelum kamu sunnah-sunnah (Allah), karena itu berjalanlah kamu ke (segenap penjuru) bumi dan perhatikanlah bagaimana kesudahan orang yang mendustakan (rasul-rasul). Inilah (al-Qur'an) suatu keterangan yang jelas untuk semua manusia dan menjadi petunjuk serta pelajaran bagi orangorang yang bertakwa. (QS. Ali Imran, (3): 137-138)

Ayat di atas memperbincangkan sejarah umat masa lalu di mana ketentuan Allah telah diberlakukan terhadap mereka yang mendustakan ayat-ayat-Nya, tidak mau beriman kepada-Nya. Manusia dituntut agar mempelajari ketentuan Allah tersebut melalui penggalan sejarah. Perintah mempelajari fenomena alam ini tergambar dalam penggalan ayat siiruu dan fandzuruu, yang berarti manusia diperintah agar mempelajari sejarah. Pernyataan al-Qur'an mengenai sejarah dan fenomena alam lainnya menjadi bayan atu ilmu bagi manusia, dan diharapkan melalui ilmu tersebut manusia mendapat petunjuk serta pelajaran, dan akhirnya dapat membuat diri menjadi insan yang shaleh 
dan bertakwa kepada Allah.

Kadar M. Yusuf (2013:83) dalam bukunya yang berjudul PesanPesan Al-Qur'an Tentang Pendidikan menerangkan bahwa "Ketakwaan dan keshalehan itu ditandai dengan kemapanan aqidah dan keadilan yang mewarnai segala aspek kehidupan seseorang; yang meliputi pikiran, perkataan, pergaulan, dan lain sebagainya." Untuk mencapai tujuan ini, terdapat empat hal yang mesti diperkenalkan kepada anak (peserta didik) melalui materi pelajaran yang diajarkan dalam setiap bidang ilmu, yaitu sebagai berikut: (Kadar M. Yusuf, 2013:83)

a. Memperkenalkan kepada mereka, bahwa manusia secara individu adalah makhluk Allah yang mempunyai tanggung jawab dalam kehidupan ini.

b. Memperkenalkan kepada mereka, bahwa manusia sebagai makhluk sosial adalah anggota masyarakat dan mempunyai tanggung jawab dalam sistem kemasyarakatan di mana ia berada.

c. Memperkenalkan kepada mereka, bahwa alam ini ciptaan Tuhan dan mengajak anak memahamni hikmah Tuhan menciptakannya. Kemudian menjelaskan pula kepada mereka kemestian manusia melestarikannya.

d. Memperkenalkan Pencipta alam kepada anak (peserta didik) dan mendorong mereka beribadah kepada-Nya.

Keempat hal di atas disebut oleh Muhammad Fadli al-Jamali (1978:71) sebagai inti dari tujuan pendidikan Islam. Menurutnya, keempat persoalan ini merupakan suatu sistem yang tidak dapat dipisahkan antara satu dari yang lain. Dan tiga hal pertama menuju atau menggiring peserta didik kepada tujuan keempat. Ia adalah tujuan utama pendidikan Islam, yaitu mengenal Allah dan bertakwa kepadaNya.

Pada dasarnya agama Islam secara jelas mengajarkan manusia untuk saling mengasihi dan melakukan perbutan yang baik. Dengan ajaran inilah, Islam memberikan petunjuk kepada manusia agar hidup secara damai penuh kasih sayang. Selain nilai kasih sayang yang ditekankan dalam ajaran Islam, nilai moralitas terkait bagaimana melakukan tindakan yang baik dan benar juga menjadi titik tekan ajaran Islam kepada manusia. 
Sigit Mangun Wardoyo (2014:63) menyimpulkan :

Manusia berpegang teguh pada ajaran Islam, ia akan menjadi insan atau manusia dengan kasih sayang dan moralitas yang baik. Akhirnya bahwa ketika manusia memiliki rasa kasih sayang dan moralitas yang tinggi, maka mereka akan mampu membangun nilai-nilai spiritualitas mereka secara sempurna.

\section{Pendidikan Moral Kids Zaman Now Menurut Islam}

Tujuan pendidikan Islam adalah "membentuk peserta didik menjadi insan yang shaleh dan bertakwa kepada Allah SWT". Artinya bertujuan untuk membentuk insane yang bermoral. Seperti yang dijelaskan di atas bahwasanya ciri-ciri anak yang bermoral menurut Islam adalah anak yang sholeh yang berbakti kepada kedua orangtuanya seperti; berbuat baik (ihsan), tidak berbicara kasar, bertutur kata yang baik dan sikap ramah. 4 sikap tersebut adalah pandangan Islam kepada anak yang memiliki moral yang baik.

Sedangkan Kids Zaman Now adalah sindiran anak muda zaman sekarang yang berperilaku nyeleneh, sering memperhatikan penampilan daripada hal yang bersifat keindahan (ihsan), pergaulan bebas, narsis di sosial media dan membuat istilah tersebut menjadi negatif di pemikiran masyarakat Indonesia.

Sebenarnya pengertian istilah kids zaman now bersifat umum, tidak semua negatif ada juga yang postif, akan tetapi hal ini sudah berulang kali disebut di sosial media atau internet tatkala melihat anak muda yang berperilaku nyeleneh dan menjadi suatu kebiasaan netizen menyebut mereka dengan sebutan kids zaman now.

Moral anak zaman sekarang di Indonesia dari zaman ke zaman semakin melemah, karena keterbebasan orangtua dalam mendidik dan orangtua membiarkan mereka untuk bergaul secara bebas, dan orangtua cenderung membiarkan anaknya menggunakan teknologi secara bebas tanpa ada pengawasan. Harusnya seorang anak diawasi dalam menggunakan hal-hal yang berbau teknologi, seperti Gadget, HP dan Internet. Walaupun keduanya mengandung manfaat yakni semakin mudahnya kita mendapatkan informasi akan tetapi jika tidak ada pengawasan oleh orangtua, anak cenderung menelusuri hal-hal yang tak sepatutnya dilihat. Dan hal inilah yang memicu anak menjadi berani berpacaran, dan narsis di sosial media tanpa etika.

Agama Islam memandang Kids Zaman Now bukan sebuah contoh dari anak yang bermoral, karena mereka tidak melakukan perbuatan 
yang Ihsan (perbuatan baik), mereka tidak memperhatikan lingkungan sekitar, etika di masyarakat, menyukai hal-hal yang praktis tanpa perlu usaha untuk mendapatkan sesuatu, dan ketergantungan pada gadget dan selfie. Islam tidak melarang hal yang baru selagi itu bermanfaat. Akan tetapi, orangtua harus lebih mengawasi anaknya dan mendidik seperti yang Islam ajarkan yakni agar menjadi anak yang soleh dan bertakwa kepada Allah SWT.

Konotasi makna kids zaman now menjadi tidak baik, jika generasi muda tidak mengetahui hakikat sesungguhnya sebuah teknologi, dan gaya hidup. Dan anak muda yang selalu bertakwa kepada Allah dan tidak mengumbar hal-hal yang tidak bermanfaat maka konotasi kids zaman now menjadi positif di kalangan masyarakat modern ini. Pendidikan Islam, peran orangtua, dan lingkungan masyarakat yang baik menjadi pertimbangan kuat dalam membuat lingkungan anak yang agamis, dan berakhlakul karimah (bermoral).

\section{Relevansi Pendidikan Moral Islam Dalam Menjawab Problematika Kids Zaman Now Di Era Modern}

Dalam situasi kemanusiaan di zaman modern, harus diakui bahwa terdapat bermacam-macam persoalan yang benar-benar membutuhkan pemecahan segera. Kadang-kadang dirasakan, bahwa situasi yang penuh dengan problematika di dunia modern ini justru disebabkan oleh perkembangan pemikiran manusia sendiri. Di balik kemajuan ilmu dan teknologi, dunia modern sesungguhnya menyimpan suatu potensi yang dapat menghancurkan martabat kemanusiaan, (Kuntowijoyo, 1991:159). Seperti halnya munculnya beberapa stigma negatif mengenai anak-anak zaman sekarang atau sering dikenal dengan Kids Zaman Now. Perubahan pemikiran anak zaman sekarang, membuat resah orangtua dan dunia pendidikan, karena dekadensi moral anak di Indonesia banyak disebabkan karena media teknologi, seperti: HP, Internet, gadget dll. Maka dari itu, orangtua dan peran pemerintah perlu mencegah dalam problematika modern ini, terutama pada generasi penerus kita. Contohnya; membuat batas usia dalam bermain internet, memblokir situs-situs pornografi, dan peduli dengan maraknya selfie anak muda-mudi tak bermoral yang beredar di dunia maya seperti di instagram, facebook, twitter dll.

Persoalan yang muncul di era modern dapat diidentifikasi sebagai persoalan fisik dan psikis. Persoalan yang bersifat fisik mengarah pada pengkondisian manusia sebagai objek dari segala produk iptek yang dihasilkan di era modern. Sementara itu persoalan yang bersifat psikis mengarah pada pendangkalan nilai-nilai moralspiritual akibat dari dominasi produk keilmuan dan teknologi modern 
yang bersifat skuler. Fenomena terjadinya Disintegrasi Ilmu, Kepribadian yang Terpecah (split personality), Penyalahgunaan Iptek, Pendangkalan Iman, Pola Hubungan Materialistik, Menghalalkan Segala Cara, Stress dan Frustasi, Kehilangan Harga Diri dan Masa Depan, adalah merupakan bagian dari problem manusia di era modern, (Johan Istiadie \&Fauti Subhan, 2013:55).

Untuk menyelamatkan manusia dari problematika era modern, perlu intensitas pendidikan moral yang ditanamkan sejak dini kepada anak-anak. Menurut Jalaluddin Rahmat, sekarang ini di seluruh dunia timbul kesadaran betapa pentingnya memperhatikan etika atau moral dalam pengembangan sains. Di beberapa Negara maju telah didirikan lembaga-lembaga "pengawal moral" untuk sains. Lembaga yang paling terkenal ialah The Institut of Society Etics and Life Science di Hasting New York. Kini telah disadari, seperti kata Sir Mac Farlance Burnet seorang Biolog Australia yang dikutip oleh Jalaludin Rahmat (1991:158), bahwa: "Sulit bagi seorang ilmuwan eksperimental mengetahui apa yang tidak boleh diketahui. Ternyata, sains tidak bisa dibiarkan lepas dari etika, kalau manusia tidak ingin senjata makan tuan".

Saat ini dunia sepakat bahwa sains harus dilandasi etika- moral, tetapi karena etika pun akarnya adalah pemikiran filsafat, yaitu pemikiran yang mengandung keunggulan dan kelemahan, maka masalah etika pun masih mengandung masalah. Untuk itu yang diperlukan adalah akhlak yang bersumber pada al-Quran dan alHadist. Terkait dengan ini, amat relevan apabila konsep dan prinsip pendidikan moral yang dikemukakan oleh Abdullah Nasih Ulwan ditanamkan kepada peserta didik sejak dini atau sejak masa kanakkanak. Johan Istiadie \&Fauti Subhan (2013:56) menyimpulkan bahwa: "Hal ini akan dapat menghindarkan diri anak jika dewasa nanti dari terkena sikap disintegrasi ilmu, karena ilmu pengetahuan yang dimiliki didasari dengan etika atau moral. Ajaran moral semacam ini juga akan menjaga manusia dari perbuatan menyalahgunakan ilmu dan teknologi".

Pendidikan moral juga harus dicontohkan dengan kebiasaan mengingat Allah SWT. Menurut Ulwan, benteng pertahanan religius yang berakar pada hati sanubari, kebiasaan mengingat Allah SWT yang telah dihayati dalam dirinya dan instropeksi diri yang telah menguasai seluruh pikiran dan perasaan, telah memisahkan anak dari sifat-sifat jelek, kebiasaan-kebiasaan dosa, dan tradisi-tradisi jahiliyah yang rusak. Setiap kebaikan akan diterima menjadi salah satu kebiasaan dan kesenangan, dan kemuliaan akan menjadi akhlak dan sifat yang 
paling utama. Jadi dasar dari pendidikan moral bagi Ulwan adalah nilai-nilai iman dan ketakwaan kepada Allah SWT. Dengan demikian ajaran moral Ulwan akan dapat menghindarkan diri seseorang dari sikap stress dan frustasi serta akan menjauhkan manusia dari pola hidup hedonistik dan materialistis. (Johan Istiadie \& Fauti Subhan, 2013:57).

Sebuah artikel Online yang ditulis oleh ISIC SUKA menjelaskan sebagai berikut:

Dalam agama Islam, kemajuan ilmu pengetahuan harus dibarengi dengan kemajuan ilmu agama, karena semakin modern kita maka semakin banyak problematika. Maka dari itu, harus adanya Integrasi-Interkoneksi yaitu upaya mempertemukan antara ilmu-ilmu agama (islam) dan ilmu-ilmu umum (sains-teknologi dan sosialhumaniora). Fungsi ilmu terhadap iman dan amal sholeh adalah: 1. Memperkuat iman, 2. Mengoptimalkan amal sholeh, 3. Allah mengangkat derajat ahli ilmu di dunia dan akhirat, 4. Ilmu sebagai pustaka para nabi, 5 . Ilmu tidak akan berkarat dan tidak akan hancur karena usia, 6. Ilmu bisa menerangi hati, 7. Ilmu sebagai pintu kebaikan dunia dan akhirat (I.S.I.C Suka-ku, Pengertian Integrasi-Interkoneksi, http://isic-suka.blogspot.co.id/2013/01/pengertian-integrasiinterkoneksi.html, diakses 5 Januari 2018 pukul 21:00).

Dari pernyataan di atas, dapat disimpulkan bahwasanya terintegrasi dan terinterkoneksinya Islam dan ilmu-ilmu umum (sainsteknologi dan sosial-humaniora), dapat menjadi solusi pada era modern khususnya problematika kids zaman now, yaitu dengan cara mengimbangi ilmu agama dengan kemajuan teknologi, dan mengupayakan menemukan titik temu antara sains dengan agama Islam. Hal ini akan membuat anak zaman sekarang menjadi anak yang tidak ketinggalan zaman (sains dan teknologi) juga menjadi anak yang berakhlakul karimah. Perspektif masyarakat juga tidak akan memandang Kids Zaman Now sebagai anak yang tidak bermoral melainkan anak yang berprestasi dan berakhlakul karimah.

\section{Analisis Hasil}

Anak adalah investasi orangtua di masa depan, dan juga penerus generasi bangsa. Jika moral anak zaman sekarang bobrok bagaimana dengan generasi penerus bangsa selanjutnya?. Oleh karena itu, agama Islam menjawab mengenai problematika yang marak di masyarakat khususnya di Internet yakni tingkah laku nyeleneh Kids Zaman Now yang tidak bermoral. Dalam Q.S al-Isra ayat 23-24 menyebutkan bahwa agama Islam mewajibkan seorang anak berbakti kepada orangtua. 
Dalam ayat tersebut juga memiliki arti ciri-ciri anak yang bermoral yaitu: Ihsan (berbuat baik), tidak bertutur kasar, anjuran bertutur yan baik dan sikap ramah.

Peran orangtua dan pemerintah adalah suatu hal penting dalam menyikapi permasalah Kids Zaman Now, yaitu orangtua sebagai pendidik pertama dalam lingkungan keluarga yakni orangtua harus dapat mendidik anak dengan landasan keimanan dan ketakwaan kepada Allah SWT. Hal ini menjadi bekal seorang anak di masa depan. Dan juga peran pemerintah dalam menjaga moral anak bangsa menjadi pertimbangan bagaimana moral bangsa di mata dunia kedepan, sebagaimana tersusun dalam UU Sisdiknas pasal 3 (Undang-Undang, No. 20 Tahun 2003) menyebutkan:

Pendidikan nasional berfungsi mengembangkan dan membentuk watak serta peradaban bangsa yang bermartabat dalam rangka mencerdaskan kehidupan bangsa, bertujuan untuk berkembangnya potensi peserta didik agar menjadi manusia yang beriman dan bertakwa kepada Tuhan Yang Maha Esa, berakhlak mulia, sehat, berilmu, cakap, kreatif, mandiri, dan menjadi warga negara yang demokratis serta bertanggung jawab.

Dalam hal yang apa-apa serba berbau sains dan teknologi, dunia sepakat bahwa sains harus dilandasi etika- moral, tetapi karena etika pun akarnya adalah pemikiran filsafat, yaitu pemikiran yang mengandung keunggulan dan kelemahan, maka masalah etika pun masih mengandung masalah. Untuk itu yang diperlukan adalah akhlak yang bersumber pada al-Quran dan al- Hadist. Integrasi dan Interkoneksi antara al-Quran al-Hadis dengan Sains menjadi solusi agar terciptanya kehidupan yang bermoral dan tanpa menghilankan kemajuan sains itu sendiri. Jadi, peran orangtua dan pemerintah secara umum harus dapat mengimbangi kemajuan sains di era modern ini dengan etika-moral kepada anak. Secara khusus orangtua yang bertakwa kepada Allah akan menjaga anaknya dengan cara menanamkan nilai islam dari dini tanpa menghalangi anak mengenal sains dan teknologi. Sehingga, menjadikan Kids Zaman Now yang berilmu serta bertakwa kepada Allah SWT.

\section{Kesimpulan}

Islam mengajarkan kepada manusia untuk menjadi manusia sempurna dengan rasa kasih sayang dan moralitas yang tinggi. Adanya rasa kasih sayang dan moralitas yang tinggi manusia akan dapat membangun nilai-nilai spiritualitas mereka yang pada akhirnya akan menutun mereka dalam berperilaku. Spiritualitas dalam diri seseorang dibangun sejak kecil agar fondasi dalam diri mereka menjadi bangunan 
yang kokoh yang tidak mudah tergoyahkan dalam mengarungi zaman globalisasi yang penuh dengan aneka ragam tantangan dan godaan.

Dalam perspektif islam, moral seorang anak adalah Ihsan (berbuat baik), tidak berkata kasar, bertutur kata yang baik dan bersikap ramah. Kids Zaman Now yang dikenal oleh masyarakat adalah anak zaman sekarang yang tidak bermoral, karena tidak adanya keseimbangan antara moral dengan sains. Oleh karena itu, peran penting orangtua dalam mendidik anak sejak dini sangatlah penting, karena akan mempengaruhi mereka di masa depan. Dan peran pemerintah juga penting di era modern ini sebagaimana tujuan pendidikan nasional yaitu untuk berkembangnya potensi peserta didik agar menjadi manusia yang beriman dan bertakwa kepada Tuhan Yang Maha Esa, berakhlak mulia, sehat, berilmu, cakap, kreatif, mandiri, dan menjadi warga negara yang demokratis serta bertanggung jawab. Dan tujuan pendidikan Islam yaitu: Memperkenalkan Pencipta alam kepada anak (peserta didik) dan mendorong mereka beribadah kepada-Nya.

Dengan kemajuan Islam tentunya cendekiawan muslim dapat menjawab problematika modern seperti dekadensi moral Kids Zaman Now, yaitu dengan cara Integrasi-Interkoneksi yaitu upaya mempertemukan antara ilmu-ilmu agama (islam) dan ilmu-ilmu umum (sains-teknologi dan sosial-humaniora). Integrasi-interkoneksi ini akan mengimbangi ilmu agama dengan kemajuan teknologi, dan mengupayakan menemukan titik temu antara sains dengan agama Islam (al-Quran dan al-hadist). Hal ini akan membuat anak zaman sekarang menjadi anak yang tidak ketinggalan zaman (sains dan teknologi) juga menjadi anak yang berakhlakul karimah. Perspektif masyarakat juga tidak akan memandang Kids Zaman Now sebagai anak yang tidak bermoral melainkan Kids Zaman Now yang berakhlakul karimah dan berprestasi dalam kemajuan sains dan teknologi. 
Akhmad Aufa Syukron - Pendidikan Moral Kids Zaman Now dalam Perspektif Islam

\section{Daftar Pustaka}

Agil H. M, Said. 2005. Aktualisasi Nilai-nilai Qur'ani dalam Ssistem Pendidikan Islam. Ciputat: PT. Ciputat Press.

Ahmad, Zainuddin bin Abdul Latif Azzubaidi. 2003. Mukhtashar Shakhikhul Bukhari. Beirut: Darul Kutb Al-Alamiyah. t.t.

Al-Quran al-Karim

Cowok, Jurnal. Kids Zaman Now Adalah Suksesor Generasi Millenials?, http://www.jurnalcowok.com/2017/10/kids-jaman-nowadalah.html, diakses 4 Januari 2018 pukul 8:30

Fadhil al-Jamali, Muhammad. 1978. Nahw Tawhid al-Fikr al-Tarbawi fi al'Alam al-Islami. Dar al-Tunisiyah.

Istiadie, Johan \& Subhan, Fauti. Pendidikan Moral Perspektif Nasih Ulwan. Jurnal Pendidikan Islam, Volume 1 No. 1 Mei 2013.

Kuntowijoyo. 1991. Paradigma Islam: Interpretasi untuk Aksi. Bandung: Mizan.

M. Yusuf, Kadar. 2013. Tafsir Tarbawi : Pesan-Pesan Al-Qur'an tentang Pendidikan, Cet.I. Jakarta: AMZAH.

Mangun Wardoyo, Sigit. Pendidikan Moralitas Anak Dalam Perspektif Islam. Jurnal Tadris, Volume 9, No. 1 Januari 2014

Maunareng, Fredy. Pengertian Istilah "Zaman Now", https://www.kompasiana.com/maunareng/59fd5d7374bbb02c5540 8b32/pengertian-istilah-zaman-now diakses 3 Januari 21:00

Munir, Ahmad \& Rofiq Adnan, Ainur. 2008. Tafsir Tarbawi: Mengungkap Pesan Al-Qur'an, Cet. I. Yogyakarta: TERAS.

Rahmat, Jalaluddin. 1991. Islam Alternatif. Bandung: Mizan.

Rohman, Mustofa. 2003. "Abdullah Nasih Ulwan: Pendidikan Nilai", dalam A. Khudori Soleh, Pemikiran Islam Kontemporer. Yogyakarta: Jendela.

Suka-ku, I.S.I.C. Pengertian Integrasi-Interkoneksi, http://isic- 
Akhmad Aufa Syukron - Pendidikan Moral Kids Zaman Now dalam Perspektif Islam

suka.blogspot.co.id/2013/01/pengertian-integrasiinterkoneksi.html, diakses 5 Januari 2018 pukul 21:00

Tea, Romel. Pengertian, Asal Usul, dan Penulisan Yang Benar , http://www.romelteamedia.com/2017/11/zaman-nowpengertian-asal-usul.html, diakses 3 Januari 2018 pukul 20:00

Undang-undang No. 20 tahun 2003

Yuni Alfiyah, Hanik. 2008. Ta'lim dan Liberasi. Surabaya: LPPM Press. 